\title{
Inleiding tot die sosiaal-wetenskaplike kritiese eksegese van Nuwe- Testamentiese tekste: Die metodologiese aanloop in die navorsingsgeskiedenis
}

\author{
Andries $\mathrm{G}$ van Aarde ${ }^{1}$ \\ Emeritus Professor: Fakulteit Teologie \\ Universiteit van Pretoria
}

\begin{abstract}
Introducing the social-scientific critical exegesis of

New Testament texts: Methodological initiators in

the research history

The article is the first of a series of three that aim to introduce socialscientific exegesis of New Testament texts. Aspects of the social background of these writings are analyzed in light of the perspectives which underlie the dynamics of first-century Mediterranean social world. The article shows that social-scientific criticism of the New Testament represents an exegetical approach by means of which the rhetoric of texts is interpreted in light of their cultural environment and the social interaction that determines this context and semeiotic codes. The first article focuses on the initiators in the field of historical-critical exegesis who paved the way to social scientific criticism and explain key facets of the "new" exegetical approach. The second article explains some models and methods of social-scientific criticism. The third article discusses some advantages of social scientific criticism and poses a critique of the approach by reflecting on the positivism that could underlie the epistemology behind some interpretation models used in social scientific criticism. It concludes with an emphasis on cultural criticism as a hermeneutical challenge.
\end{abstract}

\section{INLEIDING}

Sedert die sewentigerjare word insigte vanuit die geestes- en menswetenskappe (soos sielkunde, sosiologie en antropologie) in die eksegese van die Bybel gebruik

\footnotetext{
${ }^{1}$ Andries $\mathrm{G}$ van Aarde is 'n professoremeritus in die Departement Nuwe-Testamentiese Wetenskap, Fakulteit Teologie, Universiteit van Pretoria. Hierdie artikel is met goedkeuring 'n verwerking in Afrikaans van 'n Engelse opstel (met Stephan Joubert as mede-outeur) wat in 'n bundel oor eksegetiese metodologie en hermeneutiek in die reeks Guide to the New Testament, Volume III, onder redaksie van A B du Toit deur Protea Publishing House uitgegee word.
} 
en hierdie benadering het as "sosiaal-wetenskaplike kritiek" bekend begin staan. ${ }^{2}$ Aanvanklik was party eksegete skepties oor hierdie benadering (bv Werner Kümmel 1985). Hulle het getwyfel of hierdie benadering werklik 'n nuwe wyse van eksegetiese kennis veronderstel en of dit nie maar bestaande inligting bloot op 'n ander manier, met nuwe name en in nuwe kategorieë daarstel nie. Uiteindelik het die sosiaal-wetenskaplike kritiek tog 'n gerespekteerde plek ingeneem tussen 'n verskeidenheid ander eksegetiese benaderings. Hierdie respek het uitgekring na teologiese kringe verder as dié van eksegete (kyk o a Countryman 1988; Gill [red] [1987] 1996; Riggs 2003:940).

Vandag maak eksegete toenemend van sosiaal-wetenskaplike teorieë gebruik om die antieke wêreld se sosiale dinamiek ten opsigte van mense, groepe en kulture beter te begryp, te beskryf en te verklaar. Dit is vanuit die perspektiewe grondliggend aan hierdie sosiale dinamiek waarteen die agtergrond van Bybelse geskrifte verstaan behoort te word. Sosiaalwetenskaplike kritiek as 'n eksegetiese benadering fokus op die Mediterreense kultuur en die sosiale interaksies wat hierdie kultuur bepaal. Dit wil vanuit 'n sosiale oogpunt die sosiale konteks van die dokumente in die Bybel analiseer en die retoriek in die boodskap van die dokumente begryp in die lig van hierdie kultuur asook in die lig van sosiale interaksies en die konteks waarin die dokumente ontstaan het.

Gegewe die belangstelling in die sosiale wetenskappe as 'n wyse om die sosiale kodes te ondersoek wat in tekste geënkodeer is, kan 'n wetenskaplike studie van die Nuwe Testament dus daarby baat deur ag te slaan op die metodologie en resultate van en die problematiek rondom die sosiaal-wetenskaplike kritiese benadering. In hierdie reeks artikels word

\footnotetext{
- $\quad$ 'n kort oorsig gebied van die faktore wat gelei het tot die sosiaalwetenskaplike kritiese eksegese,

- die baanbrekers in die veld bespreek,

- $\quad$ verskeie fasette van "sosiologiese eksegese" uitgelig,

- $\quad$ ontledingsmetodes verduidelik en

- $\quad$ die voor- en nadele van sosiaal-wetenskaplike kritiek aan die orde gestel.
}

\footnotetext{
${ }^{2}$ Hiermee word erkenning gegee aan Stephan J Joubert (1992a) vir sy instemming op versoek van A B du Toit (redakteur van Guide to the New Testament, Volume III) dat Joubert se ongepubliseerde opstel, "Sosiaal-wetenskaplike analise" (voltooi in Desember 1992), as vertrekpunt en raamwerk van die skrywer se historiese oorsig van sosiaal-wetenskaplike kritiek sal dien. In die gekompakteerde Engelse weergawe van die drie aritkels word Stephan Joubert as mede-outeur aangedui.
} 
Laasgenoemde kritiese refleksie vind plaas in die laaste artikel van die reeks. Hierdie refleksie neem die kritiek in ag dat sosiaal-wetenskaplike eksegese positivisties sou wees omdat dit eksegetiese resultate determineer in terme van interpresasiemodelle wat die eksegeet op tekste sou afdwing. Die refleksie eindig met die beklemtoning van kultuurkritiek as 'n hermeneutiese uitdaging vir eksegete van Nuwe-Testamentiese tekste in kritiese teologiese konteks. In die eerste artikel word aandag aan items 1 en 2 gegee, in die tweede aan item 3 en in die derde aan items 4, 5 en 6.

\section{EKSEGETIES-METODOLOGIESE BENADERINGS WAT TOT SOSIAAL-WETENSKAPLIKE KRITIEK GELEI HET}

\section{$2.1 \quad$ Inleiding}

Die belangstelling in die sosiale wetenskappe is niks nuuts in eksegetiese werk nie. Aan die einde van die negentiende en aan die begin van die twintigste eeu het die bekende kundige oor die vroeë kerk, Adolf von Harnack (1851-1930), en teoloë en eksegete soos Ernst von Dobschütz (1904), Ernst Troeltsch ([1911] 1960), Gustav Adolf Deissmann ([1908] 1927) en Ernst Lohmeyer ([1921] 1973) belanggestel in die sosiale sy van die vroeë bewegings wat gelei het tot wat later as die Christendom bekend sou staan.

In sy beroemde werk, Licht vom Osten (in 1927 in Engels vertaal as Light from the ancient East: The New Testament illustrated by recently discovered texts of the Graeco-Roman world), het Deissmann (1866-1937) aangedui waarom hy oordeel dat Nuwe-Testamentiese geskrifte nie net literêr (teenoor 'n oorbeklemtoonde teologies-dogmatiese uitleg) verstaan behoort te word nie, maar ook sosiaal, en wel teen die agtergrond van die Griekse "volksliteratuur" van die eerste eeu. Hierdie literatuur word so genoem omdat dit dokumente is wat nie in die eerste plek as letterkundige werke bedoel was nie. Hiermee het Deissmann die papirus-literatuur (veral uit Egipte) in die oog gehad wat mededelings soos onder andere oor alledaagse koop- en verkoopkontrakte, huwelikooreenkomste, aanneming van kinders en persoonlike briewe bevat. Hy het daarop gewys dat baie van Jesus se vroeë volgelinge kleinboere (peasants) was wat nie aan die adelike stand van die aristokrasie behoort het nie - 'n standpunt wat Von Harnack ([1902] 1908) en Troeltsch (1960) met hom gedeel het. In die antieke samelewing voor industrialisering was daar basies net twee sosiale "klasse", naamlik die "boereklas" en die "adelstand". Daar was geen middelklas soos sedert industrialisasie nie (kyk Van Aarde 1993:515-545; Lenski et al [1970] 1995:217). 
Tussen die twee Wêreldoorloë was die Universiteit van Chicago 'n belangrike sentrum waar navorsing oor die sosiale ontwikkeling van die vroeë Christendom gedoen is. Die hoofverteenwoordigers van die "Chicago skool" (kyk Robert W Funk 1976:4-22; Haynes 1981) was Shirley Jackson Case en Shailer Matthews (kyk o a Case 1914, 1923; Matthews 1897). Hulle het die rol van sosiale prosesse in die vorming van die waardes van Judaïsme en die Christendom in hulle vroeëre stadia beklemtoon. Tradisioneel het Bybelwetenskaplikes verkies om klem te lê op die ontwikkeling van vroeë "Joodse" en "Christelike" bewegings in terme van literêre prosesse of institusionele faktore.

\subsection{Anakronisme}

Een van die gevolge van die bestudering van die vroegste vormende stadia van eerste-eeuse godsdienste (soos die Judaïsme en die Christendom) was Bybelwetenskaplikes se toenemende besef van die "hermeneutiese dwaling" wat anakronisme in eksegese kan inhou. Dit is die eksegetiese "fout" om dinge wat kronologies eers later in die geskiedenis sosiale verskynsels geword het, in 'n vroeëre tyd toe dit nog nie bestaan het nie, as sosiale verskynsel in tekste te veronderstel. In teologiese diskussies kom hierdie "dwaling" dikwels voor. Die gevolg is dat eksegete gewoond raak aan terme wat veronderstel was om te verwys na verskynsels in die Bybel, maar wat eintlik in Bybelse tye onbekend was. Dikwels het ' $n$ bepaalde begrip eers in die moderne tyd ontstaan, moontlik as gevolg van moderne refleksie.

So byvoorbeeld is die begrip "eskatologie", wat verwys na 'n bestudering van verskynsels wat verband hou met die einde van alle tye, 'n teologiese begrip (eintlik ' $n$ "theologoumenon" omdat dit slegs in teologiese kringe gebruik word) uit die onlangse moderne tyd (kyk o a Lauer 1981). In sy boek, Windows on the world of Jesus: Time travel to ancient Judea, het Bruce Malina (1993:156) getoon dat mense rondom die antieke Middellandse See min belanggestel het in 'n abstrakte begrip van die toekoms ('n "abstract future") en dat hulle basies op die hede gekonsentreer het (hulle was "essentially present-oriented") (kyk ook Malina [1989] 1996 se bydrae, "Christ and time: Swiss or Mediterranean").

Om anakronisme te voorkom behoort 'n mens eintlik ook nie begrippe soos "Christelik" of "Joods" te gebruik om te verwys na die inwoners van Palestina gedurende die eerste eeu of na Jesus se eerste volgelinge nie. In verband met "Jode" het sosiaal-wetenskaplike kritiek by Malina (1993:62-70) daartoe gelei dat hy voorgestel het dat ons eerder moet praat van "Mediterreense Judeërs" (vgl ook John Pilch 1997 se artikel, "Are there Jews and Christians in the Bible?"; vgl ook Pilch 1993a). Derhalwe verwys die 
begrip "Israeliete" of "Israeliet" ook nie spesifiek op "Joodse" voorsate vóór die Babiloniese ballingskap, terwyl "Jode" of "Joods" na die era ná die ballingskap sou verwys nie. In der waarheid is die term "Joods" (of "Jode") 'n anakronisme.

Die term "Judeër" (nie "Jood" nie) - 'n vertaling van die Griekse term loudaios - is 'n streeksnaam vir 'n inwoner van Judea (in Grieks: loudaia), ter onderskeiding van byvoorbeeld 'n inwoner van Galilea (in Grieks: Galilaios). Dit wil voorkom of die term "Judeër" nie 'n self-benoeming was nie. Mense wat die sosio-religieuse ideologie van die Tweede Tempel na die Babiloniese ballingskap aangehang het, dit wil sê mense vanuit die "binnekring" afkomstig uit Judea of Galilea, het na hulleself verwys as die "mense van God" of die "huis van Israel" (bv in Matt 10:6) en nie in die eerste plek as "Judeërs" nie. Uit die "binnekringperspektief" van Israel self is mense wat buite hierdie kring gestaan het, gestereotipeer as buitestaanders ( $d$ w s "outsiders") wat "nieIsraeliete" is (bv in 1 Makk 1:15 en 2 Makk 10:4). In die Bybel word daar na hulle verwys as goyim of ethnoi, wat dikwels as "heidene" (in Engels: "gentiles") vertaal word (vgl Esler 2003:55). Die Griekse woord "ethnos" (en die meervoud daarvan, "ethnol") is egter ook in Bybelse en nie-Bybelse geskrifte gebruik om te verwys na 'n versameling of groep, byvoorbeeld van plante, voëls, of mense oor die algemeen (kyk Duling 2005a:129). Uit die perspektief van 'n binnegroup ("in-group"), byvoorbeeld in Matteus, is Jesus se volgelinge nie as "Christene" getipeer nie, maar as "mense" (anthrōpoi, bv in Matt 4:19; of ethnos, bv in Matt 21:43). En tog was hierdie "mense" steeds deel van die "huis van Israel", hoewel Matteus ook "uitgeworpenes" uit beide die huis van Israel en nie-Israelietiese groepe - wat gestereotipeer is as mamzerim (in Engels: "bastards") - ingesluit het.

Die term "Christianoi" is 'n verdere voorbeeld van stereotipering wat deur die Judeërs en die Romeine gebruik is om te verwys na Jesus se volgelinge, byvoorbeeld in Sirië (vgl Hand 11:26 waar die volgelinge [mathētal] van Jesus vir die "eerste keer" "Christene" genoem is). Uit 'n "ingroep" perspektief het Matteus egter nie Jesus se volgelinge as "Christene" voorgestel nie, maar as "mense" wat 'n "kerk" (ekklēsia) gevorm het (in Matt $16: 18 ; 18: 17$ ) in teenstelling met 'n "sinagoge" (sunagōgē) (o a in Matt 9:35).

\subsection{Die historiese kritiek as oorgang}

Dit is duidelik dat sosiaal-wetenskaplike kritiese eksegese 'n noemenswaardige invloed op teologiese insigte uitgeoefen het. Eksegete se belangstelling in sosiale verskynsels in die Bybelse geskrifte het egter ' $n$ aanloop gehad. In die vroeë jare van die twintigste eeu het 'n aantal Marxistiese geskiedkundiges ook na verskeie sosiale aspekte in Bybelse 
geskrifte gekyk (kyk, o a, Miranda [1971] 1974; Boer 2003). So, byvoorbeeld, het Karl Kautsky ([1908] 1953) Jesus se vroeë volgelinge beskryf as 'n proletariese en revolusionêre beweging van die laer klasse in die Israelietiese samelewing. Toe meer "heidene" in die Grieks-Romeinse wêreld Christusvolgelinge geword het, het die kerk ook bestaan uit mense uit die meer gegoede klasse. Uit Kautsky (1982) se twintigste-eeuse Marxistiese perspektief het Christendom die geloof geword van die opgevoede "middelklas" wat maar ter wille van die beskerming van hulle eie belange saam met die regerende klas gewerk het.

Teen die 1920er jare het Bybelwetenskaplikes se belangstelling in die sosiale aspekte van die Christendom begin afneem. Dit kan hoofsaaklik toegeskryf word aan die opkoms van die Formgeschichte as een van die eksegetiese metodes in die histories-kritiese paradigma. Formgeschichte het ook 'n "sosiologiese" belangstelling (vgl Osiek 1984:3). Die belangstelling in die "sosiologiese" kontekste (die Sitze im Leben) van die vroegste Jesusbewegings (kyk o a Zimmermann [1967] 1974:145) was van 'n historiesliterêre aard (kyk Berger 1977:219). Daarvolgens veroorsaak 'n bepaalde sosiale behoefte (die Sitz im Leben) die keuse van 'n "vorm" (Gattung/Form) as 'n toepaslike draer vir die boodskap. So, byvoorbeeld, kan iemand se dood (Sitz im Leben) tot 'n klaaglied (Form) lei. Derhalwe het die "sosiologiese konteks" veroorsaak dat die raconteurs en skrywers wat die Jesus-tradisies oorgelewer het, sekere vorms gekies - soos 'n gelykenis, wonderwerk of strydgesprek - wat dan funksioneel sou wees in die oordrag van 'n boodskap na aanleiding van 'n sekere Jesus-tradisie.

Die eksegetiese resultate wat uit die Formgeschichte verkry is, het egter nie op aspekte van die sosiale dinamiek van tekste gefokus nie. Hierdie fokus word wel in die sosiologie aangetref (kyk o a Zuckermann 2003:17-23), omdat die sosiale wetenskappe geïnteresseerd is in onder andere die sosiale interaksie van individue of groepe (wat vir die skryf van tekste verantwoordelik is). Dit is egter ironies dat die prioriteit wat eksegete metodologies aan die Formgeschichte gegee het, gelei het tot 'n verminderde fokus op die bydrae wat die sosiale wetenskappe as sodanig tot die uitleg van die Bybel kan maak. Hierdie situasie het begin verander toe eksegete die waarde besef het om daadwerklik insigte vanuit onder andere die sosiologie te ontgin. ${ }^{3}$

\footnotetext{
${ }^{3}$ Vir 'n oorsig van die faktore wat tot sosiaal-wetenskaplike kritiek as 'n eksegetiese metode gelei het, kyk onder andere Gewalt (1971:87-99); Malherbe (1977:4-11); Best (1983:181194); Kümmel (1985:327-363); Kee (1989:3-4); Schmidt (1989:115-132); Schottroff (1990:247-256); Elliott (1993:17-35); Horrell (1999:309-338) en Esler (2005a:3-14).
} 


\section{FAKTORE SEDERT DIE SEWENTIGERJARE}

Tussen 1920 en die vroeë 1970er jare het daar 'n aantal publikasies verskyn wat die Christendom vanuit verskeie sosiale perspektiewe ontleed het. ' $n$ Voorbeeld hiervan is die werk van die Australiese klassikus, Edwin Judge (1960a, 1960b, 1968). Dit was egter die werk van die Britse Bybelwetenskaplike, J D M Derrett, met sy 1973-publikasie, Jesus' audience: The social and psychological environment in which he worked, wat nuwe rigting aan Bybelondersoek gegee het. In hierdie werk fokus Derrett op sosiale konvensies in die eerste-eeuse wêreld rondom die Middellandse See, soos byvoorbeeld die rol van die "bose oog" (die evil eye) (Derrett 1973:119, 123). Sedert die sewentigerjare het ander navorsers ook ander onafhanklike en oorspronklike werk in hierdie verband gelewer. ${ }^{4}$ Die werk van die NoordAmerikaners Wayne Meeks (1975) en John Gager $(1975,1982)$ - professore in Nuwe-Testamentiese Wetenskap aan onderskeidelik Yale Divinity School en Princeton University - is 'n goeie voorbeeld hiervan.

In 1975 verskyn John Gager se boek, Kingdom and community: The social world of early Christianity. In hierdie boek het hy insigte gebruik uit die kennissosiologie (oorgeneem van die sosioloë Peter Berger en Thomas Luckmann [1975]) en die sosiologiese teorie wat as kognitiewe dissonansie bekend staan (oorgeneem van Leon Festinger ]1957]). Met behulp van hierdie teorieë het Gager die apokalipties-profetiese tendense in die vroegste Jesusbewegings vergelyk met hedendaagse millennialistiese groepe (bv die sogenaamde Maleise "cargo cults"). ${ }^{5}$ In 'n interessante artikel, "The man from heaven in Johannine sectarianism", wat in 1972 verskyn het, fokus Wayne Meeks spesifiek op die rol van sosiaal-wetenskaplike teorieë in terme waarvan data vanuit die Nuwe Testament ontleed word. Ook hy maak gebruik van Peter Berger en Thomas Luckmann se kennissosiologie as teorie om die uitbeelding van Jesus as die "neerdalende en opstanende verlosser" (descending and ascending redeemer) in die Evangelie van Johannese te beskryf. Meeks toon dat daar 'n dialektiese verhouding tussen die Johannese gemeenskap se ervaringe en hulle simboliese wêreld bestaan het. Volgens sy

\footnotetext{
${ }^{4}$ Kenners van die Nuwe Testament wat 'n beslissende rol in die renaissance van die "sosiologiese" eksegese gedurende die 1970er, 1980er en vroeë 1990er jare gespeel het, was Wayne Meeks (1975), John Gager (1975, 1982), Gerd Theissen ([1974a] 1983, 1974b, [1977] 1978, [1979] 1983), Robin Scroggs (1980), Paul W Hollenbach (1981) en H C Kee (1982b, 1989, 1991).

5 'n Soortgelyke belangstelling in kognitiewe dissonansie, wat verwys na Gager se baanbrekerswerk met erkenning aan die invloed van Gerd Theissen, is onlangs deur Per Bilde (2005:118-135) uitgespreek in sy artikel in Evangelische Theologie (65/2), "Kognitive Dissonanzreduktion in der Jesusbewegung: Ein sozialpsychologischer Beitrag zum Verständnis neutestamentlicher Texte".
} 
interpretasie het "Jode" vir lede van die Johannese gemeenskap uit die sinagoges verban, op grond van hulle siening van Christus. Die vervreemding wat hulle as gevolg van hierdie situasie ervaar het, is op Jesus geprojekteer. Dit het daartoe gelei dat Jesus uitgebeeld is as ' $n$ vreemdeling wat nie deur sy eie mense aanvaar en verstaan is nie. Op hierdie wyse het die Evangelie van Johannes die simboliese wêreld van sy lesers bevestig en hulle sosiale identiteit onderskraag.

Benewens ' $n$ aantal ander publikasies in die veld van "sosiologiese eksegese", het Meeks in 1983 nog 'n ander belangrike monografie gepubliseer, met die titel The first urban Christians: The social world of the apostle Paul. Hierdie werk fokus op verskeie sosiale fasette van die Pauliniese gemeenskappe en beskryf hoe dit was om in die eerste eeu ' $n$ Christen te word en te wees ("what it was like to become and be an ordinary Christian in the first century") (Meeks 1983:2; vgl ook Meeks [1983] 1999). Meeks maak op 'n eklektiese wyse gebruik van wyd uiteenlopende sosiaalwetenskaplike teorieë en modelle om data in die Paulusbriewe te ondersoek. Hy verwys hierna as sy piecemeal theory (Meeks 1983:6).

In 'n metodologiese oorsigartikel met die opskrif "The social description of early Christianity" het Jonathan Z Smith (1975) vier verskillende velde van die sogenaamde "sosiologiese" benadering geïdentifiseer: (a) die beskrywing van sosiale data in die Nuwe Testament en in die kontemporêre literatuur van daardie tyd; (b) die ontwikkeling van 'n sosiale geskiedenis van die vroeë Christendom binne die konteks van die sosio-politieke omgewing; (c) die ontleding van die sosiale instellings van die vroegste kerk, en (d) die ondersoek na die sosiale en simboliese wêrelde van vroeë Christene.

Laasgenoemde fokus in die besonder op die simbole, rolle, rites, rituele en taalgebruik wat aanleiding gegee het tot hulle sosiale wêrelde (bv Grainger [1988] 2000; Bernstein [1971] 1975). Voorbeelde van sulke sosiologiese ontledings kan gevind word in studies wat die politieke, argeologiese en filologiese aspekte van, byvoorbeeld, die Pauliniese gemeenskappe beklemtoon, ${ }^{7}$ dié van die Markusgemeenskap, ${ }^{8}$ dié van die

\footnotetext{
${ }^{6}$ Vir die rede waarom die term "Jode" in aanhalingstekens geplaas word, kyk opmerkings oor anakronisme in afdeling 2.2 hierbo.

${ }^{7}$ Byvoorbeeld A Funk (1981); Meeks (1983); Malina (1986c); McDonald (1988); Neyrey (1990); Craffert (1993, 1994); Horrell (1996, [1997] 1999).

${ }^{8}$ Byvoorbeeld Myers (1988); Waetjen (1989); Van Eck ([1994] 1995]).
} 
Matteusgemeenskap, ${ }^{9}$ dié van die Lukasgemeenskap, ${ }^{10} 1$ Petrus, ${ }^{11} 2$ Petrus, ${ }^{12}$ Judas, ${ }^{13}$ Openbaring, ${ }^{14}$ eksegetiese kommentaar op (a) die Sinoptiese Evangelies,$^{15}$ (b) die Johannesevangelie, ${ }^{16}$ (c) die boek Openbaring ${ }^{17}$. In hierdie kader vind 'n mens ook "algemene" studies oor die sosiale wêreld van die "vroeë Christendom" as sulks. ${ }^{18}$

Sommige ontledings het 'n eng fokus op konsepte soos die "historiese Jesus", ${ }^{19}$ die koninkryk van God, ${ }^{20}$ eer en skande, ${ }^{21}$ sektariese bewegings en kultusse, ${ }^{22}$ "stigmatisering en charisma", ${ }^{23}$ mag en voorregte ("power and privilege"), ${ }^{24}$ leierskap en outoriteit, ${ }^{25}$ rituele, ${ }^{26}$ transformasierites soos die doop,${ }^{27}$ veranderende bewussynstoestande (alternated states of

\footnotetext{
${ }^{9}$ Byvoorbeeld Crosby (1988); Syreeni (1990); White (1991); Saldarini (1991, 1992, 1994]); Segal (1991); Overman (1990); Vledder \& Van Aarde (1994, 1995); Neyrey (1998b); Carter (2000, 2001);

${ }^{10}$ Byvoorbeeld Esler ([1987] 1996; Stegemann (1991); Van Staden (1991); Scheffler (1993).

${ }^{11}$ Byvoorbeeld Elliott ([1981] 1990, 2000).

${ }^{12}$ Byvoorbeeld Malan \& Van Aarde (1999).

${ }^{13}$ Byvoorbeeld Joubert $(1989,1990)$.

${ }^{14}$ Byvoorbeeld Malina (1995b); Malina \& Pilch (2000).

${ }^{15}$ Byvoorbeeld Malina \& Rohrbaugh (1992).

${ }^{16}$ Byvoobeeld Malina \& Rorhrbaugh (1998).

${ }^{17}$ Byvoorbeeld Malina \& Pilch (2000).

${ }^{18}$ Byvoorbeeld Stambaugh \& Balch (1986); Horsley \& Hanson (1985); Saldarini (1988); Kyrtatas ([1987] 1988); Fiensy (1991); Van Aarde (1994b); Malina $(1993,1996)$.

${ }^{19}$ Byvoorbeeld Craffert (2001a, 2002a, 2003a, 2003b, 2006); Craffert \& Botha (2000); Van Aarde (2002).

${ }^{20}$ Byvoorbeeld Malina (2001).

${ }^{21}$ Byvoorbeeld Neyrey (1998a, 1998b); Moxnes (1996:19-40).

${ }^{22}$ Byvoorbeeld Wilson (1973), Stark (1986), Stark \& Bainbridge (1985), Smith (1980), Scroggs ([1975] 1999); Craffert (2001c).

${ }^{23}$ Byvoorbeeld Mödritzer (1994).

${ }^{24}$ Byvoorbeeld Holmberg (1978).

${ }^{25}$ Byvoorbeeld Schütz (1975), Horrell ([1997] 1999), Dreyer (2002).

${ }^{26}$ Byvoorbeeld MacDonald (1988); DeMaris (2002).

${ }^{27}$ Byvoorbeeld McVann (1991a, 1991b).
} 
consciousness), ${ }^{28}$ veranderende bewussynstoestande wat verband hou met gesigte (visies), ${ }^{29}$ apokaliptiek, ${ }^{30}$ opstandingservarings, ${ }^{31}$ "loop op water, ${ }^{32}$ geestesbesetting/demoniese besetting, ${ }^{33}$ die rol van imperiale magte, ${ }^{34}$ siekte en siektes (sickness en disease), ${ }^{35}$ shamanisme in Jesusstudies, ${ }^{36}$ Jesus se genesings, ${ }^{37}$ en die vroegste doop en nagmaal as "antisamelewingsverbalisasie" van veranderde bewussyn. ${ }^{38}$

In ander studies is aspekte uit die sosiale wêreld van die "vroeë Christene" vergelyk met religieuse groepformasie in die antieke tyd. Sommige van hierdie studies ondersoek die sosio-ekonomiese situasie van die "vroeë Christene" ${ }^{39}$ en armoede. ${ }^{40}$ Ander fokus op spesifieke aspekte soos hulle maaltye,${ }^{41}$ simboliese universum, ${ }^{42}$ groepformasie, ${ }^{43}$ beskermheerskap (oftewel patronage), ${ }^{44}$ konflik, ${ }^{45}$ die proses van institutionalisering en de-

\footnotetext{
${ }^{28}$ Byvoorbeeld Pilch (1993b, 1995, 1996, 1997a, 1997b, 2002), Craffert (2002b).

${ }^{29}$ Byvoorbeeld Pilch (2002).

${ }^{30}$ Byvoorbeeld Van Aarde (2001b).

${ }^{31}$ Byvoorbeeld Pilch (1998a, 2003); Craffert (1989, 2002c, 2005); Van Aarde (2001a:180186).

${ }^{32}$ Byvoorbeeld Pilch (1998b); Craffert \& Botha (2000).

${ }^{33}$ Byvoorbeeld Davies (1995).

${ }^{34}$ Byvoorbeeld Duling (2005b).

${ }^{35}$ Byvoorbeeld Pilch (1995, 1986, 1988, 1991a, 1992, 1995, 2000); Craffert (1999a).

${ }^{36}$ Byvoorbeeld Craffert (1999b).

${ }^{37}$ Byvoorbeeld Pilch (2000); Van Aarde (2000).

${ }^{38}$ Kyk die DD-proefskrif (Universiteit van Pretoria) van Jonanda Groenewald (2005) en vergelyk Groenewald \& Van Aarde (2006:41-67).

${ }^{39}$ Byvoorbeeld Robin Smith (1980); Oakman (1986, 1991, 1992, 1996).

${ }^{40}$ Byvoorbeeld Hollenbach (1987); Malina (1986b:148-159); Van Aarde (1996:947-964).

${ }^{41}$ Byvoorbeeld J H Elliott (1991); Dennis E Smith (2003).

${ }^{42}$ Byvoorbeeld Joubert (1992b, 1992c).

${ }^{43}$ Byvoorbeeld Malina (1995c).

${ }^{44}$ Byvoorbeeld Elliott (1987); Malina (1988a); Joubert (2000, 2005); Osiek (2005a).

${ }^{45}$ Byvoorbeeld Duling (1997, 1998); Vledder ([1994] 1997).
} 
institutionalisering - waarna ook verwys word as structuration theory, ${ }^{46}$ marginalisasie, ${ }^{47}$ etnitisiteit en sosiale identiteit, ${ }^{48}$ en "anti-samelewing" (met ander woorde, die "subversiewe" aard van Jesus en sy eerste volgelinge. ${ }^{49}$ Ander studies konsentreer weer op aspekte soos gesinswaardes ${ }^{50}$ en die rol van kinders in die antieke tyd. ${ }^{51}$

\section{4. 'N INTERDISSIPLINÊRE BENADERING}

Talle van hierdie studies bou voort op die navorsing van sosioloë, antropoloë, en psigoloë. In teenstelling met 'n taamlik arbitrêre seleksie uit sosiologiese insigte, waarna John Gager (1979) verwys as "sosiale beskrywing", het 'n aantal Bybelwetenskaplikes doelbewus besluit om hulle "sosiologiese benadering"52 te baseer op bepaalde sosiologiese modelle (kyk Pilch 2001). 'n Sodanige sosiologiese model bou 'n bepaalde teorie en perspektief uit. John $\mathrm{H}$ Elliott (emeritus professor van die University of San Francisco) was die eerste Bybelwetenskaplike wat na so 'n ontleding van Bybelse data verwys het as "sosiaal-wetenskaplike kritiek". ${ }^{53}$

\section{DIE ROL VAN DIE CONTEXT GROUP}

Die feit dat hierdie benadering so vinnig veld onder eksegete begin wen het, is toe te skryf aan die produktiewe skryfwerk van 'n hele aantal pioniers op die

\footnotetext{
${ }^{46}$ Byvoorbeeld Horrell ([1997] 1999:309-338); Dreyer (2000, 2001, 2002).

${ }^{47}$ Byvoorbeeld Duling (1993, 1995, 2002).

${ }^{48}$ Byvoorbeeld Duling (2005); Esler (2003); Stegemann (2004); Cromhout (2005); Van Aarde (2006).

${ }^{49}$ Byvoorbeeld Malina \& Rohrbaugh (1998:7).

${ }^{50}$ Byvoorbeeld Oliver \& Van Aarde (1991), Osiek \& Balch (1997), Van der Watt $(2000,2001)$, Osiek (2005b).

${ }^{51}$ Byvoorbeeld Van Aarde (2004), Bakke (2005).

52 'n Term wat P J Richter gebruik het in 'n oorsigartikel wat in 1984 verskyn het.

${ }^{53}$ Vir 'n verduideliking van die onderskeid tussen "sosiale beskrywing" en "sosiaalwetenskaplike kritiek", kyk onder andere Osiek 1984:24-66; 1989, 1992; Rohrbaugh 1987a, 1987b; Domeris 1988; Jan Botha 1989; Craffert 1991; en die artikel deur Piet van Staden en Andries van Aarde wat in 1991 in Hervormde Teologiese Studies (47, bls 55-87), getitel "Social description or social-scientific interpretation? A survey of modern scholarship", gepubliseer is as ' $n$ hersiene weergawe van 'n gedeelte van $P$ van Staden se DD-proefskrif wat in 1990 deur die Universiteit van Pretoria aanvaar is onder die leiding van A G van Aarde.
} 
gebied. ${ }^{54}$ Sedert die 1970er jare het baie van hierdie Bybelwetenskaplikes die kern gevorm van 'n navorsingsgroep, onder leiding van John Elliott (en John Kloppenborg sedert 2007), wat hulleself die "Context Group. Project on the Bible in Its Cultural Environment" noem en wat sedert 1990 jaarliks in die VSA bymekaarkom. ${ }^{55}$

Die "oorsprong" van die Context Group is die "Working Group van die Social World of Early Christianity" van die Society of Biblical Literature (SBL) en die American Academy of Religion (AAR) (ondersteun deur Wayne Meeks en Abraham Malherbe) en die sogenaamde BASTARDs ("Bay Area Society for Theology and Related Disciplines"), wat deur John Elliott en Norman Gottwald georganiseer was. Terselfdertyd het verskeie taakgroepe onder die beskerming van die Catholic Biblical Association aktief geraak en het hulle Bybelwetenskaplikes soos Bruce Malina (Greighton University), Jerome Neyrey (University of Notre Dame), John Elliott (University of San Francisco) en John Pilch (Georgetown University) betrek. Dit het daartoe gelei dat Bruce Malina in 1976 amptelik die "Task Group on the Social Sciences and the New Testament" onder voogdyskap van die Catholic Biblical Association gevorm het.

\footnotetext{
${ }^{54}$ Name wat vermeld kan word, is dié van Bruce Malina (1978a, 1978b, [1981] 1993, 1982, 1986a), John Elliott ([1981] 1990), Richard Rohrbaugh (1978, 1984, 1987a, 1987b), John J Pilch $(1985,1986,1988,1991)$, Douglas Oakman $(1986,1991)$, Jerome H Neyrey (1986, 1988a, 1988b, 1991a, 1991b, 1991c), Halvor Moxnes (1988), Philip F Esler ([1987] 1996), Dennis Duling (2003) en Ou-Testamentiese kenners soos Norman K Gottwald (1979, 1983), K C Hanson [\& D Oakman] (1998), R R Wilson (1984), J W Rogerson (1978, 1989), en Victor $\mathrm{H}$ Matthews (tesame met Don C Benjamin) (1993) (kyk die oorsigartikel oor OuTestamentiese studies in Hervormde Teologiese Studies 56[1] 2000, 137-173, deur P Kruger).

${ }^{55}$ Die Context Group het ook internasionale vergaderings gehou in Medina del Campo in Spanje (1991), St Andrews in Skotland (1994), Praag in Pole (1997), Tützing in Duitsland (1999), Pretoria in Suid-Afrika (2001), St Petersburg in Rusland (2005) en Salamanca in Spanje (2006) (kyk 'n "outobiografiese" oorsig van die Context Group Project deur Philip F Esler 2005b:46-61).
} 
In 1986 het Robert W Funk die Westar Institute (gesetel in Santa Rosa, Kalifornië) gestig en het hy die bekende Jesus Seminar gevestig. ${ }^{56}$ Die stigtingsvergadering in Redlands, Kalifornië, het die moontlikheid ondersoek van die samesmelting van die twee seksies van die Society of Biblical Literature (SBL), naamlik die Social History of Early Christianity Section en die Social Sciences and New Testament Interpretation Section. Op uitnodiging van Robert Funk ('n voormalige president van die SBL), het John Elliott die voorsitter geword van die Social Facets groep wat parallel met die Jesus Seminar vergader het vanaf 1986 tot 1989. In 1986 het John Elliott volume 35 van Semeia, getiteld "Social-scientific criticism of the New Testament and its social world" geredigeer, onder die vaandel van die Social Sciences and New Testament Interpretation Section van die SBL. In samewerking met die Jesus Seminar het Bruce Malina and Jerome H Neyrey die boek Calling Jesus names: The social value of labels in Matthew in 1988 gepubliseer deur Funk se Westar Institute se Polebridge Press. Twee ander invloedryke publikasies wat uit hierdie gesamentlike onderneming gespruit het, was 'n versameling essays oor Markus 7:1-13 en die Beelzebul-perikoop in die Westar Institute se vaktydskrif Foundations \& Facets Forum (Volume 4[3], 1988; met 'n inleiding deur Robert Funk $)^{57}$ en een oor Openbaring genaamd Listening: Journal of Religion and Culture (Volume 28, 1993), onder die redaksie van Mark McVann.

In 1989 het Robert Funk die Social Facets Group ontbind (kyk Esler 2005b:51). Gedurende die SBL se jaarlikse byeenkoms in 1989 in New Orleans het voormalige sleutellede van die Westar Institute se Social Facets Group, in die besonder diegene wat belang gestel het in die toepassing van sosiaal-wetenskaplike modelle op die eksegese van die Nuwe Testament, besluit om die Context Group te stig met John H Elliott as voorsitter. ${ }^{58}$ Die Context Group ontmoet nou reeds sedert 1990 gereeld op 'n jaarlikse basis in Maart, eers aanvanklik in Portland, Oregon en later alternatiewelik in Ashton (naby Philadelphia,

\footnotetext{
${ }^{56}$ Kyk veral die twee publikasies wat deur die Westar Institute se Polebridge Press (Sonoma, CA) uitgegee is, te wete Funk \& Hoover (and The Jesus Seminar) ([1993] 1997) en Funk (and The Jesus Seminar) (1998).

${ }^{57}$ Nog twee bydraes deur John Elliott het in Forum verskyn: "Patronage and clientism in early Christian society: A short reading guide" (Forum 3, 39-48) in 1987, en "The fear of the leer: The evil eye from the Bible to L'il Abner" (Forum 4, 77-85) in 1988.

${ }^{58}$ John H Kloppenborg (Trinity College, Toronto, Kanada) neem sedert 2007 waar as voorsitter.
} 
Pennsylvania) naas Portland. Die deelnemers kom nie net van die VSA af nie, maar ook van Kanada, Duitsland, die Verenigde Koninkryk, Australië, Suid-Afrika, Spanje, Italië, en België..$^{59}$

Navorsing wat reeds tydens die era van die Social Facets Group gedoen is, het gelei tot publikasies soos The social world of Luke-Acts (1991), onder redakteurskap van Jerome $\mathrm{H}$ Neyrey, en Biblical social values and their meaning: $A$ handbook (1993), onder redakteurskap van John J Pilch en Bruce J Malina. Na aanleiding van die internasionale vergaderings is baie van die aanbiedings van die Medina del Campo vergadering in Spanje in 1991 gepubliseer in Volume 22 van die Biblical Theology Bulletin (1992), onder redakteurskap van David Bosman. Die bydrae van die St Andrews ontmoeting in Skotland het in 1995 verskyn. Die volume se titel was Modelling early Christianity, en Philip F Esler was die redakteur. Die Tützing-bydraes het onder redakteurskap van Wolfgang Stegemann (Augustana Hochschule, Neuendettelsau, Duitsland), Bruce Malina (Greighton University, VSA) en Gerd Theissen (Heidelberg, Duitsland) het in 2004 in Duits verskyn (onder die titel Jesus in neuen Kontexten) uitgegee deur Kohlhammer Verlag, en in Engels deur Fortress Press (onder die titel The social setting of Jesus and the Gospels). Die meeste van die bydraes wat aangebied is by die ontmoeting by die Universiteit van Pretoria (gereël deur Eugene Botha, Stephan Joubert, Pieter Craffert en Andries van Aarde) het in 2002 verskyn in Hervormde Teologiese Studies, Volume 58(2), onder redakteurskap van Andries van Aarde.

Lede van die Jesus Seminar wat van sosiologiese insigte gebruik gemaak het (insigte wat hulle onder andere ontleen het aan die werk van lede van die Context Group) in hulle rekonstruksie van aspekte van die lewe van die historiese Jesus, is Bybelwetenskaplikes soos John Dominic Crossan, ${ }^{60}$ Bernard Brandon Scott ${ }^{61}$ en Andries G van Aarde. ${ }^{62}$

Die oorvleueling van sekere dissiplines het veral bygedra tot die oplewing in die bydrae wat deur mens- en gedragswetenskappe in die

\footnotetext{
${ }^{59}$ Andries van Aarde van Suid-Afrika, skrywer van hierdie reeks artikels, is die enigste lid wat sedert 1990 deurgaans deelgeneem het aan beide die Jesus Seminar en die Context Group.

${ }^{60}$ Kyk Crossan, J D 1991. The historical Jesus: The life of a Mediterranean Jewish peasant. San Francisco, CA: Harper.

${ }^{61}$ Kyk Scott, B B [1989] 1990. Hear then the parable: A commentary on the parables of Jesus. Minneapolis, MN: Fortress.

${ }^{62}$ Kyk Van Aarde, A G 2001a. Fatherless in Galilee: Jesus child of God. Harrisburg, PA: Trinity Press International.
} 
studie van die Nuwe Testament gemaak is. ${ }^{63}$ Hierdie dissiplines sluit byvoorbeeld psigologie, ${ }^{64}$ sosiologie ${ }^{65}$ en antropologie ${ }^{66}$ in.

Subdissiplines soos mediese antropologie ${ }^{67}$ en ekonomie ${ }^{68}$ het ook gefigureer. Al hierdie ontwikkelinge het Bybelwetenskaplikes daartoe gelei om die impak van sosiale prosesse op die vorming en groei van die vroeë Christendom te herevalueer - soos uitgewys deur veral J P Martin (1987) in sy voordrag voor die Studiorum Novum Testamenti Societas in Cambridge (Engeland), getitel "Towards a post-critical paradigm" ${ }^{\text {"69 }}$ en W S Vorster (1988) se bydrae, getitel "Toward a post-critical paradigm: Progress in New Testament scholarship?". ${ }^{70}$

\footnotetext{
${ }^{63}$ Een van die faktore wat "sosiologiese eksegese" beïnvloed het, was die wêreldwye klem op sosiale vraagstukke in die 1960er en 1970er jare. Gerd Theisssen in Duitsland en Richard Horsley in die VSA het bekendheid verwerf vir hulle belangstelling in politieke vraagstukke van die eerste eeu $\mathrm{nC}$ en die implikasies daarvan vir die bestudering van die Nuwe Testament (kyk bv Theissen 1995a, 1995b, 2002 en Horsley 1987, 1996, 2003).

${ }^{64}$ Kyk onder andere Theissen (1983); Pilch (1997a:112-116); Ellens \& Rollins et al (2004); Leiner (2005).

${ }^{65}$ Kyk onder andere Holmberg (1990); Stegemann \& Stegemann (1995); Horrell et al (1999).

${ }^{66}$ Kyk onder andere die oorsigartikel deur Jerome H Neyrey (1986:160-170), "Social Science modeling and the New Testament", gebaseer op die boek deur Bruce J Malina (1986a), Christian origins and Cultural Anthropology: Practical models for Biblical interpretation.
}

${ }^{67}$ Kyk veral die werk van John Pilch, in die besonder sy ongepubliseerde oorsig wat aangebied is by die Social Scientific Criticism deel van die Society of Biblical Literature Meeting in Philadelphia (PA) op Sondag, 20 November 2005, "The New Testament and social sciences after thirty years: Retrospect". Vergelyk verder sy werke "Healing in Mark: A social science analysis" (1985), BTB 15, 142-150; "The health care system in Matthew: A social science analysis" (1986), BTB 16, 102-106; "Understanding biblical healing: Selecting the appropriate model" (1988), BTB 18, 60-66; "Sickness and healing in Luke-Acts", in Neyrey, J H (ed) 1991, The social world of Luke-Acts: Models for interpretation, 181-210;

"Understanding healing in the social world of early Christianity" (1992), BTB 22, 26-33; "Insights and models from medical anthropology for understanding the healing activity of the historical Jesus" (1995), HTS 51(2), 314-337. Pilch se boek (2000) bevat 'n versameling van die meeste van sy bydraes op hierdie gebied, getitel Healing in the New Testament: Insights from medical and Mediterranean anthropology. Minneapolis, MN: Fortress. Vergelyk ook Craffert (1997, 1999a).

${ }^{68}$ Kyk veral die werk van Douglas E Oakman (1986), Jesus and the economic questions of his day. New York: Edwin Mellen. Vergelyk verder sy werke "The ancient economy in the Bible" (1991), BTB 21(1), 34-39; "Was Jesus a peasant? Implications for reading the Samaritan story (Luke 10:30-35)" (1992), BTB 22, 117-125; "The ancient economy", in Rohrbauch, R L (ed) 1996, The social sciences and New Testament interpretation, 126-143. Peabody, MA: Hendrickson.

${ }^{69}$ Martin, J P 1987. Towards a post-critical paradigm. NTS 33, 370-385.

${ }^{70}$ Vorster, W S 1988. Toward a post-critical paradigm: Progress in New Testament scholarship?, in Mouton, J, Van Aarde, A G \& Vorster, W S (eds), Paradigms and progress in theology, 31-48. Pretoria: Human Research Council. 


\section{METODOLOGIESE DOSETISME?}

Nog 'n rede vir die oplewing van sosiaalwetenskaplike kritiek was die feit dat eksegete daarvan beskuldig is dat hulle nie genoeg aandag geskenk het aan die verband tussen geloofsaffirmasies wat in die Bybel uitgedruk word en die sosiale kontekste waarbinne dit plaasgevind het nie (kyk o a De Villiers 1984:66-79). Robin Scroggs (1980:164-179) het na hierdie verontagsaming van politieke, ekonomiese en kulturele aspekte verwys as "methodological docetism".

In Duitsland het Gerd Theissen ([1974] 1983a) ook sterk die "kerugmatiese eksegese" (veral beoefen in die Barth- en Bultmann-skole deur dialektiese teoloë) gekritiseer, omdat dit nie werklik die sosiale en menslike verhoudings in ag neem wat agter tekste soos byvoorbeeld die Nuwe-Testamentiese verhale oor wonderwerke in die Nuwe Testament verskuil lê nie. Hy vind dit problematies as ons te geredelik die realiteite van die angs vir siekte, honger en die dood uit die oog verloor deurdat ons sodanige tekste bloot kognitief benader en dus hulle sosiale alledaagse betekenis omskep in idees asof hierdie tekste in vakuum sonder raakpunte met die grondvlak van die samelewing ontstaan het. Theissen toon oortuigend dat wondervertellings in die antieke tyd (insluitende dié in die Bybel) gefunksioneer het te midde van sosiale konflik. Dit is tekste wat gedien het as die legitimering van sekere ideologiese belange (vgl Van Aarde 1994a:210; Vledder [1994] 1997).

\section{SAMEVATTING}

Bogenoemde bespreking van die metodologiese aanloop in die navorsingsgeskiedenis van die sosiaal-wetenskaplike kritiese eksegese van Nuwe-Testamentiese tekste het die volgende resultate aan die lig gebring. In die eerste plek duidelik geword dat teoloë toenemend die eksegetiese benaderings wat deur moderne Westerse vraagstukke opgeroep is, nie onkrities geïmplementeer het nie. Hierdie benaderings het dikwels die onaanvaarbare gees van etnosentrisme geadem. Dit is 'n probleem wat eksegete moeilik kan vermy. Uit die aard van eksegese word die sosiale dinamiek van Bybelse tye in dialoog met eie-tydse kulturele vraagstukke gebring. Die feit dat dit gebeur, is op sigself nie die probleem nie. Die hermeneutiek van Bybelse tekste vereis so 'n dialogiese betrokkenheid. Eksegete word egter slagoffers van etnosentrisme wanneer hulle in hulle 
"betrokke hermeneutiek" (engaged hermeneutics) ${ }^{71}$ nie genoegsaam tussen kulture onderskei nie. Dit geld die kultuur van die antieke tyd in onderskeid met die moderne of postmoderne kultuur. Dit geld ook, wat die antieke tyd betref, tussen die oos-Mediterreense (bv die Semitiese) en die wesMediterreense (bv die Grieks-Romeinse) kultuur en wat die moderne/postmoderne tyd betref tussen byvoorbeeld die kulture van die "Eerste"- en "Derde" wêrelde. Die onderskeid tussen verskillende wêrelde is dus werksaam op beide 'n sinchroniese en 'n diachroniese vlak.

Om etnosentrisme te voorkom is om nie die kultuur van die geïnterpreteerde monosentries vanuit die lens van die kultuur van die interpreteerder te interpreteer nie. Dit impliseer 'n bewussyn dat die sosiale dinamiek van kulture in dieselfde periode nie noodwendig dieselfde is nie. Hierdie insig is des te meer toepaslik op kulture wat deur tyd geskei is. Bybelwetenskaplikes behoort in ag te neem dat die Bybel meer as twee duisend jaar gelede in 'n homogene agraries-kulturele gemeenskap ontstaan het, ${ }^{72}$ terwyl die hedendaagse sosiale realiteit dié is van 'n geïndustrialiseerde en post-geïndustrialiseerde "wêrelddorp" (global village). So kan ons byvoorbeeld nie die Bybel interpreteer asof die industriële revolusie nooit plaasgevind het nie en asof dit nie ons sosiale persepsiepatrone radikaal verander het nie (vgl Holmberg 1990:133; Rohrbauch 1987b:113).

Benewens etnosentrisme het die kritiek op tradisionele historiese kritiek daarop gesentreer dat Formgeschichte nie daarin geslaag het om tot die essensie van die sosio-historiese inligting oor die Jesus-tradisies in die Evangelies deur te dring nie. Dit - en 'n toenemende ontevredenheid oor die "tradisionele" ondersoeke na die Umwelt van die vroeë Christendom - het gelei tot 'n stroom publikasies oor die agtergrond tot die Nuwe Testament. Die studie van die omliggende konteks(te) van die vroeë Christendom is dikwels meer onderneem met die doel om 'n beter begrip van die Nuwe Testament te verkry, eerder as om hierdie sosiale kontekste in hulle eie reg te ondersoek.

Die "sosiologiese teksondersoek" as sulks was dus nie die fokuspunt nie. Die histories-kritiese formgeschichtliche, traditionsgeschichtliche en redaktionsgeschichtliche ondersoeke is as die werklike eksegetiese metodes beskou. Dit is vir hierdie rede dat die "sosiologiese" ondersoek maklik in die slaggat getrap het om bronne eklekties en sonder enige uitdruklike teoretiese

\footnotetext{
${ }^{71}$ Kyk onder andere Van Aarde 1994c. Kultuurimperialisme as 'n hermeneutiese dilemma: Eerste-wereldse en Derde-wereldse perskpektiewe op Jesus as die Seun van God. HTS 50(1\&2), 354-367; Van Aarde, A G1994d. The epistemic status of the New Testament and the emancipatory living of the historical Jesus in engaged hermeneutics. Neotestamentica 28(2), 575-596.

${ }^{72}$ Kyk onder andere Van Aarde 1993. Aspekte van die sosiale stratifikasie van die ontwikkelde agragriese samelewing in die eerste-eeuse Palestina. HTS 48(3\&4), 515-545.
} 
basis te hanteer (kyk De Villiers 1982:19-32). Informasie uit verskeie bronne is doodeenvoudig gekombineer en is dan aangebied as rekonstruksies van "wat werklik gebeur het". Hierdie agtergrondinligting is dan beskou as die vertrekpunt vir die "werklike" eksegetiese metodes, soos die Redaktionsgeschichte en die Traditionsgeschichte. Ontevredenheid met hierdie stand van sake het gelei tot 'n pleidooi dat die ondersoek na die so genoemde "agtergrond" van die Nuwe Testament na die voorgrond toe moes verskuif (kyk o a Tidball 1983).

As gevolg van die onlosmaaklike verband tussen geloofsaffirmasies in die tekste van die Nuwe Testament en hulle sosio-kulturele kontekste is kennis insake hierdie sosiale kontekste nie slegs 'n vertrekpunt vir eksegese nie, maar behoort dit ook 'n wesenlike deel van die eksegetiese proses te vorm.

\section{Literatuurverwysings}

Bakke, O M 2005. When children became people: The birth of childhood in early Christianity, tr by B McNeil. Minneapolis, MN: Fortress.

Berger, K 1977. Exegese des Neuen Testaments: Neue Wege vom Text zur Auslegung. Heidelberg: Quelle und Meyer.

Berger, P L \& Luckmann, T 1975. The social construction of reality: A treatise in the sociology of knowledge. Harmondsworth: Penguin.

Bernstein, B B [1971] 1975. Class, codes and control, Vol 1: Theoretical studies towards a sociology of language. London: Schocken.

Best, T F 1983. The sociological study of the New Testament: Promise and peril of a new discipline. SJTH 36, 181-194.

Bilde, P 2005. Kognitive Dissonanzreduktion in der Jesusbewegung: Ein sozialpsychologischer Beitrag zum Verständnis neutestamentlicher Texte. EvTh 65(2), 118-135.

Boer, R 2003. Marxist criticism of the Bible. London: T \& T Clark International. (A Continuum Imprint.)

Botha, J 1989. Sosio-historiese en sosiologiese interpretasie van die Nuwe Testament. Koers 54, 480-508.

Carter, W 2000. Matthew and the margins: A sociopolitical and religious reading. Maryknoll, NY: Orbis.

Carter, W 2001. Matthew and Empire: Initial explorations. Harrisburg, PA: Trinity Press International.

Case, S J 1914. The evolution of early Christianity. Chicago, IL: University of Chicago Press.

Case, S J 1923. The social origins of Christianity. Chicago, IL: Chicago University Press.

Countryman, L W [1988] 1989. Dirt, greed and sex: Sexual ethics in the New Testament and their implications for today. Second printing. Philadelphia, PA: Fortress. 
Craffert, P F 1989. The origins of resurrection faith: The challenge of a socialscientific approach. Neotestamentica 23, 331-348.

Craffert, P F 1991. Towards an interdisciplinary definition of social-scientific interpretation of the New Testament. Neotestamentica 25, 109-122.

Craffert, P F 1993. The Pauline movement within first-century Judaism: A framework for transforming the issues. Neotestamentica 27(2), 233-262.

Craffert, P F 1994. 'n Herdefiniëring van Paulus se konflik in Galasië: Die brief aan die Galasiërs deur die bril van die sosiale wetenskappe. HTS 50(4), 859-876.

Craffert, P F 1997. Opposing world-views: The border guards between traditional and biomedical health care practices. South African Journal of Ethnology 20(1), 19.

Craffert, P F 1999a. Illness, health and healing in the New Testament world: Perspectives of health care. Pretoria: Biblia.

Craffert, P F 1999b. Jesus and the shamanic complex: First steps in utilizing a social type model. Neotestamentica 33(1), 321-342.

Craffert, P F 2001a. Jesus van Nasaret as historiese figuur: Die rol van wêreldbeelde en interpretasiestyle. Fragmente 7, 101-115.

Craffert, P F 2001b. An exercise in the critical use of models: The "goodness of fit" of Wilson's sect model, in Pilch, J J (ed), Social scientific models for interpreting the Bible: Essays by the Context Group in honour of Bruce J Malina, 21-46. Leiden: Brill.

Craffert, P F 2002a. Historical-anthropological Jesus research: The status of authentic pictures beyond authentic material. HTS 58(2), 440-471.

Craffert, P F 2002b. Religious experiences and/as (alternate) states of consciousness from a biopsychosocial perspective, in Du Toit, C W (ed), Brain, mind and soul: Unifying the human self, 53-97. Pretoria: Research Institute for Theology and Religion.

Craffert, P F 2002c. Seeing a body into being: Reflections on scholarly interpretations of the nature and reality of Jesus' resurrected body. Religion \& Theology 9(1\&2), 89-107.

Craffert, P F 2003a. Crossan's historical Jesus as healer, exorcist and miracle worker. Religion \& Theology 10(3\&4), 243-266.

Craffert, P F 2003b. Mapping current South African Jesus research: The Schweitzerstrasse, the Wredebahn and cultural bundubashing. Religion \& Theology 10(3\&4), 339-377.

Craffert, P F 2005. What on earth (or in heaven) is a resurrected body? The outline of a historical-anthropological answer, in Chatelion Counet, P \& Berges, U (eds), One text, a thousand methods: Essays in memory of Sjef van Tilborg, Leiden: Brill.

Craffert, P F \& Botha, P J J 2000. Why Jesus could walk on the sea but could not read and write: Reflections on historicity and interpretation in historical Jesus research. Neotestamentica 39(1), 5-38.

Cromhout, M 2005. The reconstruction of Judean ethnicity in Q. PhD Dissertation, University of Pretoria.

Crosby, M H 1988. House of disciples: Church, economics and justice in Matthew. Maryknoll, NJ: Orbis.

Crossan, J D 1991. The historical Jesus: The life of a Mediterranean Jewish peasant. San Francisco, CA: Harper. 
Davies, S L 1995. Jesus the healer: Possession, trance, and the origins of Christianity. New York: Continuum.

Deissmann, G A [1908] [1927] 1965. Light from the ancient east: The New Testament illustrated by recently discovered texts of the Graeco-Roman world, tr by L R M Strachan. New York: Doran. Reprinted. Grand Rapids, MI: Baker.

DeMaris, R E 2002. The baptism of Jesus: A ritual-critical approach, in Stegemann, W, Malina, B J \& Theissen, G (eds), The social setting of Jesus and the Gospels, 137-157. Minneapolis, MN: Fortress.

Derrett, J D M 1973. Jesus's audience: The social and psychological environment in which he worked. New York: Seabury. (A Crossroad Book.)

De Villiers, P G R 1982. Renaissance van die sosiologiese teksanalise. Theologica Evangelica 15, 19-32.

De Villiers, P G R 1984. The interpretation of a text in the light of its socio-cultural setting. Neotestamentica 18, 66-79.

Dreyer, Y 2000. Institutionalization of authority and titles used for Jesus. PhD Dissertation, University of Pretoria.

Dreyer, Y 2001. Reading the New Testament from the perspective of social theory of Institutionalization. Koers 66(3), 159-176.

Dreyer, Y 2002. Leadership in the world of the Bible: (De)institutionalistion as an ongoing process. Verbum et Ecclesia 23(3), 625-641.

Domeris, W R 1988. Social scientific study of the early christian churches: New paradigms and old questions, in Mouton, J, Van Aarde, A G \& Vorster, W S (eds), Paradigms and progress in theology, 378-393. Pretoria: HSRC.

Duling, D C 1993. Matthew and marginality, in Lovering, E H (ed), Society of Biblical Literature 1993 Seminar Papers 32, 642-672. Atlanta, GA: Scholars Press. Revised and reprinted in HTS 51(1), 1-30.

Duling, D C 1995. The Matthean brotherhood and marginal scribal leadership, in Esler, P F (ed), Modelling early Christianity: Social-scientific studies of the New Testament in its context, 159-182. London: Routledge.

Duling, D C 1997. Egalitarian ideology, leadership, and factional conflict in the Matthean gospel. BTB 27, 124-37.

Duling, D C 1998. Matthew 18:15-17: Conflict, confrontation, and conflict resolution in a "fictive" kin association, in Society of Biblical Literature 1998 Seminar Papers, Part One, 253-295. Atlanta, GA: Scholars Press. Reprinted in BTB 29(1), 4-22.

Duling, D C 2002. Matthew as marginal scribe in an advanced agrarian society. HTS $58(2), 520-575$.

Duling, D C 2003. The New Testament: History, literature, and social context. $4^{\text {th }}$ ed. Belmont: Wadsworth. (A Division of Thomson Learning Academic Resource Center.)

Duling, D C 2005a. Ethnicity, ethnocetrism, and the Matthean ethnos. BTB 35(4), 125-143. (Paper presented at the $57^{\text {th }}$ General Meeting of Studiorum Novi Testamenti Societas, Bonn, Germany 2003.)

Duling, D C 2005b. Empire: Theories, methods, models, Riches, J \& Sim, D C (eds), The Gospel of Matthew in its Roman imperial context, 49-74. London: T \& T Clark. (Early Christianity in Context. JSNTSS 276.) 
Ellens, J H \& Rollins, W G (eds) 2004. Psychology and the Bible: A new way to read the Scriptures. 4 Volumes. Westport, Conn: Praeger. (Praeger Perspectives: Psychology, Religion, and Spirituality.)

Elliott, J H [1981] 1990. A home for the homeless: A sociological exegesis of 1 Peter. Its situation and strategy. $2^{\text {nd }}$ expanded edition. Philadelphia, PA: Fortress.

Elliott, J H 1987. Patronage and clientism in early Christian society: A short reading guide. Forum 3, 39-48.

Elliott, $\mathrm{J} \mathrm{H}$ 1988. The fear of the leer: The evil eye from the Bible to L'il Abner. Forum 4, 77-85.

Elliott, $\mathrm{J} \mathrm{H} 1991$. Household and meals versus the temple purity system: Patterns of replication in Luke-Acts. BTB 21(3), 102-108.

Elliott, J H 1993. What is social-scientific criticism? Minneapolis, MN: Fortress. (Guides to Biblical Scholarship.)

Elliott, J H 2000. 1 Peter: A new translation with introduction and commentary. New York: Doubleday. (The Anchor Bible.)

Esler, P F [1987] 1996. Community and gospel in Luke-Acts: The social and political motivations of Lucan theology. Reprinted. Cambridge: Cambridge University Press.

Esler, P F (ed) 1995. Modeling early Christianity: Social-scientific studies of the New Testament in its context. London: Routledge.

Esler, P F 2003. Conflict and identity in Romans: The social setting of Paul's letter. Minneapolis, MN: Fortress.

Esler, P F 2005a. Social scientific models in biblical interpretation, in Esler, P F (ed), Ancient Israel: The Old Testament in its social context, 3-14. Minneapolis, MN: Fortress.

Esler, P F 2005b. The Context Group Project: An autobiographical account, in Lawrence, L J \& Aguilar, M I (eds), Anthropology \& biblical studies: Avenues of approach. 46-61. Leiden: Deo.

Festinger, L 1957. The theory of cognitive dissonance. New York: Stanford University Press.

Fiensy, D A 1991. The social history of Palestine in the Herodian period: The land is mine. Lewiston, NY: Edwin Mellen Press. (Studies in the Bible and Early Christianity 20.)

Funk, A 1981. Status und Rollen in den Paulusbriefen: Eine inhaltsanalytische Untersuchung zur Religionssoziologie. München: Tyrolla-Verlag.

Funk, R W 1976. The watershed of the American biblical tradition: The Chicago School, first phase, 1892-1920. JBL 95, 4-22.

Funk, R W \& Hoover R W (and The Jesus Seminar) [1993] 1997. The Five Gospels: The search for the authentic words of Jesus. New York: Macmillan Publishing Company. (A Polebridge Book.)

Funk, R W (and The Jesus Seminar) 1998. The acts of Jesus: What did Jesus really do? San Francisco: HarperSanFrancisco. (A Polebridge Book.)

Gager, J 1975. Kingdom and community: The social word of early Christianity. Englewood Cliffs, NJ: Prentice Hall.

Gager, J 1979. Social description and sociological explanation in the study of early Christianity: A review essay. $R S R 5,174-180$.

Gager, J 1982. Shall we marry our enemies? Sociology and the New Testament. Interpretation 36, 256-265. 
Gewalt, D 1971. Neutestamentliche Exegese und Soziologie. EvTh 31, 87-99.

Gill, R (ed) [1987] 1996. Theology and sociology: A reader. Expanded edition. London: Cassell.

Gottwald, N K 1979. The tribes of Yahweh: A sociology of the religion of liberated Israel, 1250-1050 BC. London: SCM.

Gottwald, N K (ed) 1983. The Bible and liberation: Political and social hermeneutics. Maryknoll, NY: Orbis.

Grainger, R [1988] 2000. The message of the rite: The significance of Christian rites of passage. Cambridge: Lutterworth Press.

Groenewald, J 2005. Baptism, Eucharist, and the earliest Jeus-groups - from the perspective of alternate states of consciousness. DD Disseration, University of Pretoria.

Groenewald, J \& Van Aarde, A G 2006. The role alternate states of consciousness played in the baptism and Eucharist of the earliest Jesus-followers. HTS 62(1), 41-67.

Haynes, W J 1981. Shirley Jackson Case and the Chicago School: The sociohistorical method. Chico, CA: Scholars Press.

Hanson, K C \& Oakman, D E 1998. Palestine in the time of Jesus: Social structures and social conflicts. Minneapolis, MN: Fortress.

Hollenbach, $P$ 1987. Defining rich and poor using social sciences, in Richards, $\mathrm{K} \mathrm{H}$ (ed), Society of Biblical Literature: Seminar papers 1987, 50-63. Atlanta, GA: Scholars Press.

Holmberg, B 1978. Paul and power: The structure of authority in the primitive church as reflected in the Pauline epistles. Lund: CWK Gleerup. (ConBNT 11.)

Holmberg, B 1990. Sociology and the New Testament: An appraisal. Minneapolis, $\mathrm{MN}$ : Fortress.

Horrell, D G 1996. The social ethos of the Corinthian correspondence: Interests and ideology from 1 Corinthians to 1 Clement. Edinburgh: T\&T Clark.

Horrell, D G [1997] 1999. Leadership patterns and the development of ideology in early Christianity. Pages 309-338, in Horrell, D G (ed), Social-scientific approaches to New Testament interpretation, 309-338. Edinburgh: T \& T Clark.

Horrell, D.G. 1999. Introduction: Social-scientific interpretation of the New Testament. Retrospect and Prospect, in Horrell, D G (ed), Social-scientific approaches to New Testament interpretation, 3-27. Edinburgh: T \& T Clark.

Horsley, R A 1987. Jesus and the spiral of violence: Popular Jewish resistance in Roman Palestine. San Francisco, CA: Harper \& Row.

Horsley, R A 1996. Archeology, history, and society in Galilee: The social context of Jesus and the rabbis. Valley Forge, PA: Trinity Press International.

Horsley, R A 2003. Jesus and the Empire: The kingdom of God and the new world disorder. Minneapolis, MN: Augsburg Fortress.

Horsley, R A \& Hanson, J S 1985. Bandits, prophets, and messiahs: Popular movements at the time of Jesus. New York: Trinity Press International.

Joubert, S J 1988. Die Judasbrief: 'n Simboliese universum in die gedrang. HTS 44, 613-635.

Joubert, S J 1990. Language, ideology and the social context of the letter of Jude. Neotestamentica 24, 335-349. 
Joubert, S J 1992a. Sosiaal-wetenskaplike analise, ongepubliseerde opstel, voltooi in Desember 1992, op versoek van A B du Toit vir opname in ongerealiseerde NG Kerk Boekhandel publikasie van Band 3 van Handleiding by die Nuwe Testament, onder redaksie van A B du Toit.

Joubert, S J 1992b. Van werklikheid tot werklikheid: Die interpretasie en interkulturele kommunikasie van Nuwe-Testamentiese waardes. Scriptura 41, 55-65.

Joubert, S J 1992c. Wanneer die onmoontlike moontlik word: Paulus as verkondiger en bouer van 'n nuwe universum. NGTT 33, 301-310.

Joubert, S J 2000. Paul as benefactor: Reciprocity, strategy and theological reflection in Paul's collection. Tübingen: Mohr Siebeck. (WUNT 2/124.)

Joubert, S J 2005. Charis in Paul: An investigation into the apostle's "performative" application of the language of grace within the framework of his theological reflection on the event/process of salvation, in Van der Watt, J G (ed), Salvation in the New Testament: Perspectives on soteriology, 187-211. Leiden: Brill. (Supplements to Novum Testamentum 121.)

Judge, E A 1960a. The early Christians as a scholastic community. JRH 1, 4-15, 125-137.

Judge, E A 1960b. The social pattern of the Christian groups in the first century: Some prolegomena to the study of New Testament ideas of social obligation. London: Tyndale.

Judge, E A 1968. Paul's boasting in relation to contemporary professional practice. Australian Biblical Review 16, 37-50.

Kautsky, K [1908] 1953. Foundations of Christianity, tr by H F Mins. New York: Russell \& Russell.

Kautsky, K 1982. The politics of aristocratic empires. Chapel Hill, NC: University of North Carolina Press.

Kee, H C (with H C Mühlenberg) 1982. Das Frühe Christentum in soziologischer Sicht: Methoden und Anstosse. Göttingen: Vandenhoeck und Ruprecht. (UTB für Wissenschaft: Uni-Taschenbucher 1219.)

Kee, H C 1989. Knowing the truth: A sociological approach to New Testament interpretation. Minneapolis, MN: Fortress.

Kee, H C et al 1991. Christianity: A social and cultural history. New York: MacMillan.

Kruger, P 2000. Sosiologiese en antropologiese insigte en die studie van die Hebreeuse Bybel: 'n Bestekopname. HTS 56(1), 137-173.

Kümmel, W G 1985. Das Urchristentum, 11: Arbeiten zu Spezialproblemen. b: Zur Sozialgeschichte und Soziologie der Urkirche. ThR 50, 327-363.

Kyrtatas, D J [1987] 1988. The social structure of early Christian communities. London: Verso.

Lauer, R H 1981. Temporal man: The meaning and uses of social time. New York: Praeger.

Leiner, M 2005. Neutestamentliche Exegese zwischen "Psycholatrie" und "Psychophobie". Evangelische Theologie 65(2), 148-154.

Lenski, G, Lenski, J \& Nolan P [1970] 1995. Human societies: An introduction to macrosociology. Seventh edition. New York: McGraw-Hill.

Lohmeyer, E [1921] 1973. Soziale Fragen im Urchristentum. Leipzig: Teubner. Reprinted. Darmstadt: Wissenschaftliche Buchgesellschaft. 
MacDonald, M Y 1988. The Pauline churches: A socio-historical study of institutionalization in the Pauline and Deutero-Pauline writings. Cambridge: Cambridge University Press.

Malan, G J \& Van Aarde, A G 1999. Invloed van die Mediterreense tydsbegrip op die betekenis van die dag van die Here in 2 Petrus. HTS 55(1), 209-220.

Malherbe, A J 1977. Social aspects of early Christianity. Baton Rouge, LA: Louisiana State University Press.

Malina, B J 1978a. Limited good and the social world of early Christianity. BTB 8, 162-176.

Malina, B J 1978b. The social world implied in the letters of the Christian bishopmartyr (named Ignatius of Antioch), in Achtemeier, P J (ed), Society of Biblical Literature Seminar papers,71-119. Missoula, MT: Scholars.

Malina, B J [1981] 1993. The New Testament world: Insights from cultural anthropology. Revised Edition. Louisville, KY: Westminster.

Malina, B J 1982. The social sciences and biblical interpretation. Interpretation 37, 229-242.

Malina, B J 1986a. Christian origins and cultural anthropology: Practical models for biblical interpretation. Atlanta, GA: John Knox.

Malina, B J 1986b. Interpreting the Bible with anthropology: The case of the poor and the rich. Listening 21, 148-159.

Malina, B J 1986c. Religion in the world of Paul. BTB 16, 92-101.

Malina, B J 1986d. The received view and what it cannot do: 3 John and hospitality. Semeia 35, 171-194.

Malina, B J 1988. Patron and client: The analogy behind Synoptic theology. Foundations \& Facets Forum 4(1), 1-32.

Malina, B J [1989] 1996. Christ and time: Swiss or Mediterranean?, in Malina, B J, The social world of Jesus and the Gospels. 179-214. London: Routledge. Original version published in $C B Q 51,1-31$.

Malina, B J 1993. Windows on the world of Jesus: Time travel to ancient Judea. Louisville, KY: Westminster/John Knox.

Malina, B J 1995a. Early Christian groups: Using small group formation theory to explain Christian organizations in Esler, P F (ed), Modelling early Christianity: Social-scientific studies of the New Testament in its context, 96-113. London: Routledge.

Malina, B J 1995b. On the genre and message of Revelation: Star visions and sky journeys. Peabody, MA: Hendrickson.

Malina, B J 1996. The social world of Jesus and the Gospels. London: Routledge.

Malina, B J 2001. The social gospel of Jesus: The kingdom of God in Mediterranean perspective. Minneapolis, MN: Fortress.

Malina, B J \& Neyrey, J H 1988. Calling Jesus names: The social value of labels in Matthew. Sonoma, CA: Polebridge.

Malina, B J \& Pilch, J J 2000. Social-science commentary on the Book of Revelation. Minneapolis, MN: Fortress.

Malina, B J \& Rohrbaugh, R L 1992. Social-science commentary on the Synoptic Gospels. Minneapolis, MN: Fortress.

Malina, B J \& Rohrbaugh, R L 1998. Social-science commentary on the Gospel of John. Minneapolis, MN: Fortress.

Martin, J P 1987. Towards a post-critical paradigm. NTS 33, 370-385. 
Matthews, S 1897. The social teaching of Jesus: An essay in Christian sociology. New York: Macmillan.

Matthews, V C \& Benjamin, D C 1993. Social world of Ancient Israel 1250-587BCE. Peabody, MA: Hendrickson.

McVann, M 1991a. Baptism, miracles, and boundary jumping in Mark. BTB 21, 151157.

McVann, M 1991b. Rituals as status transformation in Luke-Acts, in Neyrey, $\mathrm{J} \mathrm{H}$ (ed), The world of Luke-Acts: Models for interpretation, 333-360. Peabody, MA: Hendrickson.

McVann, M (ed) 1993. The Apocalypse of John in social-scientific perspective. Listening: Journal of Religion and Culture 28(3). University Microfilm International, Ann Arbor, MT.

Meeks, W A 1972. The man from heaven in Johannine sectarianism. JBL 91, 44-72

Meeks, W A 1975. The social world of early Christianity. The Council on the Study of Religion Bulletin 6(1), 4-5.

Meeks, W A 1983. The first urban Christians: The social world of the apostle Paul. New Haven, CT: Yale University Press.

Miranda, J P [1971] 1974. Marx and the Bible: A critique of the philosophy of Oppression, tr by J Eagleson. Maryknoll, NY: Orbis.

Mödritzer, H 1994. Stigma und Charisma im Neuen Testament und seiner Umwelt: Zur Soziologie des Urchristentums. Göttingen: Vandenhoeck \& Ruprecht. (Novum Testamentum et Orbis Antiquus 28.)

Moxnes, H 1988. Sociology and the New Testament, in Karisaune, E (ed), Religion as a social phenomenon: Theologians and sociologists sharing research concerns, 143-159. The articles were produced upon the occasion of a Nordic seminar in sociology of religion at the Dept. of Religious Studies at the University of Trondheim in June 1987. Trondheim: Tapir. (Relieff 25.)

Moxnes, H 1996. Honor and shame, in Rohrbaugh R L (ed), The social sciences and New Testament interpretation, 19-40. Peabody, MA: Hendrickson.

Myers, C 1988. Binding the strong man: A political reading of Mark's story of Jesus. New York: Orbis.

Neyrey, J H 1986. Social science modeling and the New Testament. Review article: Bruce J. Malina 1986, Christian origins and cultural anthropology: Practical models for biblical interpreation. Atlanta, GA: John Knox Press. BTB 16, 160170.

Neyrey, J H 1988a. An ideology of revolt: John's Christology in social-science perspective. Philadelphia, PA: Fortress.

Neyrey, J H 1988b. A symbolic approach to Mark 7. Foundations \& Facets Forum 4, 31-62.

Neyrey, J H 1990. Paul, in other words: A cultural reading of his letters. Louisville, $\mathrm{KY}$ : Westminster.

Neyrey, J H 1991a. Preface, in Neyrey, J H (ed), The social world of Luke-Acts: Models for interpretation, ix-xviii. Peabody, MA: Hendrickson.

Neyrey, J H 1991b. The symbolic universe of Luke-Acts: "They turn the world upside down", in Neyrey, J H (ed), The world of Luke-Acts: Models for interpretation. 271-304. Peabody, MA: Hendrickson. 
Neyrey, J H 1991c. Ceremonies in Luke-Acts: The case of meals and table fellowship, in Neyrey, $\mathrm{J} \mathrm{H}$ (ed), The world of Luke-Acts: Models for interpretation, 361-387. Peabody, MA: Hendrickson.

Neyrey, J H 1998a. Honor and shame in the Gospel of Matthew. Louisville, KY: Westminster. (Studies in the Bible and Early Christianity 8.)

Neyrey, J H 1998b. Questions, chreiai, and challenges to honor: The interface of rhetoric and culture in Mark's gospel. CBQ 60(4), 657-681.

Oakman, D E 1986. Jesus and the economic questions of his day. Lewiston, NY: Edwin Mellen Press.

Oakman, D E 1991. The ancient economy in the Bible. BTB 21(1), 34-39.

Oakman, D E 1992. Was Jesus a peasant? Implications for reading the Samaritan story (Luke 10:30-35). BTB 22, 117-125.

Oakman, D E 1996. The ancient economy, in Rohrbauch, $R \mathrm{~L}$ (ed), The social sciences and New Testament interpretation, 126-143. Peabody, MA: Hendrickson.

Oliver, W H \& Van Aarde, A G 1991. The community of faith as dwelling place of the Father: Basileia toû Theoû as "household of God" in the Johannine farewell discourse(s). Neotestamentica 25(2), 379-400.

Osiek, C 1984. What are they saying about the social context of the New Testament? New York: Paulist Press.

Osiek, C 1989. The new handmaid: The Bible and the social sciences. Theological Studies 50, 260-278.

Osiek, C 1992. The social sciences and the Second Testament: Problems and challenges. BTB 22(2), 88-95.

Osiek, C 2005a. Diakonos and prostatis: Women's patronage in early Christianity. HTS 61, 347-370.

Osiek, C 2005b. Family matters, in Horsley, R A (ed), A people's history of Christianity, Volume 1: Christian origins, 201-220. Mineapolis, MN: Fortress.

Osiek, C \& Balch, D L 1997. Families in the New Testament world: Households and house churches. Louisville, KY: Westminster.

Overman, J A 1990. The Gospel of Matthew and formative Judaism: A study of the social world of the Matthean community. Minneapolis, MN: Fortress.

Pilch, J J 1985. Healing in Mark: A social science analysis. BTB 15, 142-150.

Pilch, J J 1986. The health care system in Matthew: A social science analysis. BTB 16, 102-106.

Pilch, J J 1988. Understanding biblical healing: Selecting the appropriate model. BTB 18, 60-66.

Pilch, J J 1991. "Beat his ribs while he is young" (Sir 30:12): Cultural insights on the suffering of Jesus. Unpublished paper, presented at the Context Group Meeting in March 1992, Portland, OR.

Pilch, J J 1991. Sickness and healing in Luke-Acts, in Neyrey, J H (ed), The social world of Luke-Acts: Models for interpretation, 181-210. Peabody, MA: Hendrickson.

Pilch, J J 1992. Understanding healing in the social world of early Christianity. BTB 22, 26-33.

Pilch, J J 1993a. Jews or Judeans: A translation challenge. Modern Liturgy 20, 19. 
Pilch, J J 1993b. Visions in Revelation and altered consciousness: A perspective from cultural anthropology. Listening: Journal of Religion and Culture 28(3), 231-244.

Pilch, J J 1995. Insights and models from medical anthropology for understanding the healing activity of the historical Jesus. HTS 51(2), 314-337.

Pilch, J J 1996. Altered states of consciousness: A "kitbashed" model. BTB 26(3), 133-138.

Pilch, J J 1997a. Review Article: Davies, S L 1995, Jesus the healer: Possession, trance, and the origins of Christianity, New York, NY: Continuum. BTB 27(2), 71-72.

Pilch, J J 1997b. Psychological and psychoanalytical approaches to interpreting the Bible in social-scientific context. BTB 27(3), 112-116.

Pilch, J J 1997c. Are there Jews and Christians in the Bible? HTS 53(1\&2), 19-25.

Pilch, J J 1998a. Appearances of the risen Jesus in cultural context: Experiences of alternate reality. BTB 28(2), 52-60.

Pilch, J J 1998b. A window into the biblical world: Walking on the sea. Bible Today 36(2), 117-123.

Pilch, J J 2000. Healing in the New Testament: Insights from medical and Mediterranean anthropology. Minneapolis, MN: Fortress.

Pilch, J J (ed) 2001. Social scientific models for interpreting the Bible: Essays by the Context Group in honor of Bruce J Malina. Leiden: Brill.

Pilch, J J 2002. Altered states of consciousness in the Synoptics, in Stegemann, W, Malina, B J \& Theissen, G (eds), The social setting of Jesus and the Gospels. 103-116. Minneapolis, MN: Fortress. German version 2002: Ereignisse eines verändertem Bewusstseinszustandes bei den Synoptikern, in Stegemann, W, Malina, B J \& Theissen, G (Hrsg), Jesus in neuen Kontexten, 33-42. Stuttgart: Kohlhammer.

Pilch, J J 2003. A window into the biblical world: Consciousness, science, and the resurrrection appearances. Bible Today 41(4), 254-258.

Pilch, J J \& Malina, B J 1993. Biblical social values and their meaning: A handbook. Peabody, MA: Hendrickson.

Riggs, J W 2003. Postmodern Christianity: Doing theology in the contemporary world. Harrisburg, PA: Trinity Press international.

Richter, P J 1984. Recent sociological approaches to the study of the New Testament. Religion 14, 77-90.

Rogerson, J W 1978. Anthropology and the Old Testament. Oxford: Blackwell. (Growing Points in Theology.)

Rogerson, J W 1989. Anthrolopogy and the Old Testament, in Clements, R E (ed), The world of ancient Israel: Sociological anthropological and political perspectives, 17-31. Cambridge: Cambridge University Press.

Rohrbaugh, R L 1978. The biblical interpreter: An agrarian Bible in an industrial age. Philadelphia, PA: Fortress.

Rohrbaugh, $R \mathrm{~L}$ 1984. Methodological considerations in the debate over the social class status of early Christians. JAAR 52(3), 519-546.

Rohrbaugh, R L 1987a. Models and muddles: Discussions of the Social Facets Seminar. Forum 3(2), 23-33.

Rohrbauch, R L 1987b. "Social location of thought" as a heuristic construct in New Testament study. JSNT 30, 103-119. 
Saldarini, A J 1988. Pharisees, scribes and Sadducees in Palestinean society. Delaware, $\mathrm{OH}$ : Glazier.

Saldarini, A J 1991. The Gospel of Matthew and Jewish-Christian conflict, in Balch, D $\mathrm{L}$ (ed), Social history of the Matthean community: Cross-disciplinary approaches, 38-61. Minneapolis, MN: Fortress.

Saldarini, A J 1992. The Gospel of Matthew and Jewish-Christian conflict, in Levine, L I (ed), The Galilee in late antiquity, 23-38. Cambridge, MA. Republished version in Balch, D (ed) 1991. Social history of the Matthean community: Cross-disciplinary approaches. Minneapolis, MN: Fortress.

Saldarini, A J 1994. Matthew's Christian-Jewish community. Chicago, IL:The University of Chicago Press. (CSHJ.)

Schmidt, T E 1987. Hostility to wealth in the Synoptic Gospels. Sheffield: Sheffield Academic Press.

Schottroff, L 1990. Nicht viele Mächtige: Annäherungen an eine Soziologie des Urchristentums, in Schotroff, L (Hrsg), Befreiungserfahrungen: Studien zur Sozialgeschichte des Neuen Testaments. 247-256. München: Kaiser.

Schütz, J H 1975. Paul and the anatomy of apostolic authority. Cambridge: Cambridge University Press.

Scott, B B [1989] 1990. Hear then the parable: A commentary on the parables of Jesus. Minneapolis, MN: Fortress.

Scott, J C 1990. Domination and the arts of resistance. New Haven, CT: Yale University Press.

Scroggs, R 1975. The earliest Christian communities as sectarian movement, in Neusner, J (ed), Christianity, Judaism and other Greco-Roman cults, Volume 2, 1-23. Leiden: Brill. Republished version, in Horrell, D G (ed) 1999. Socialscientific approaches to New Testament interpretation, 69-91. Edinburgh: T \& T Clark.

Scroggs, R 1980. The sociological interpretation of the New Testament. NTS 26, 164-179.

Segal, A F 1991. Matthew's Jewish voice, in Balch, D L (ed), Social history of the Matthean community, 3-37. Minneapolis, MN: Fortress.

Segovia, F F 1998. Biblical criticism and postcolonial studies: Towards a postcolonial optic, in Sugirtharajah, R S (ed), The postcolonial Bible: Bible and postcolonialism, 1, 49-65. Sheffield: Sheffield Academic Press.

Smith, D E 2003. From symposium to Eucharist: The banquet in the early Christian world. Minneapolis, MN: Fortress.

Smith, J Z 1975. The social description of early Christianity. $R S R 1,19-21$.

Smith, J Z 1982. Imagining religion: From Babylon to Jonestown. Chicago, IL: University of Chicago Press. (Chicago Studies in the History of Judaism.)

Smith, $\mathrm{RH}$ 1980. Were the early Christians middle-class? A sociological analysis of the New Testament. Currents in Theology and Mission 7, 260-276.

Stambaugh, J F \& Balch, D L 1986. The New Testament in its social environment. Philadelphia, PA: Fortress.

Stark, R 1986. The class basis of early Christianity: Inferences from a sociological model. tudies in Anthropology and Comparative Religion 47, 216-225.

Stark, R \& Bainbridge, W S 1985. The future of religion: Secularization, revival, and cult formation. Berkeley, CA: University of California Press. 
Syreeni, K 1990. Between heaven and earth: On the structure of Matthew's symbolic universe. JSNT 40, 3-13.

Stegemann, W 2004. The emergence of God's new people: The beginnings of Christianity reconsidered. Annali di storia dell' esegesi 21(2), 497-513.

Stegemann, E W \& Stegemann, W 1995. Urchristliche Sozialgeschichte: Die Anfänge im Judentum und die Christusgemeinden in der mediterranen Welt. Stuttgart: Kohlhammer.

Stegemann, E W \& Stegemann, W [1995] 1999. The Jesus movement: A social history of its first century, tr by O C Dean. Edinburgh: T\&T Clark.

Stegemann, W, Theissen, G \& Malina, B J (Hrsg), Jesus in neuen Kontexten. Stuttgart: Kohlhammer.

Theissen, G 1974. Theoretische Probleme religions-soziologischer Forschung und die Analyse des Urchristentums. Neue Zeitschrift für systematische Theologie und Religionsphilosophie 16, 35-56.

Theissen, G [1977] 1978. Sociology of early Palestinian Christianity. Philadelphia, PA: Fortress.

Theissen, G [1979] 1983. Studien zur Soziologie des Urchristentums. Tübingen: Mohr. (WUNT 19.)

Theissen, G 1983. Psychologische Aspekte paulinischer Theologie. Göttingen: Vandenhoeck \& Ruprecht. (FRLANT 131.)

Theissen, G [1989] 1992. The gospels in context: Social and political history in the synoptic tradition. Edinburgh: T \& T Clark.

Theissen, G 1995a. "Geben ist seliger als nehmen" (Apg 20, 35): Zur Demokratisierung antiker Wohltätermentalität im Urchristentum, in Boluminski, A (Hrsg), Kirche, Recht und Wissenschaft: FS Albert Stein, 195215. Neuwied: Luchterhand.

Theissen, G 1995b. Urchristlicher Liebeskommunismus: Zum "Sitz im Leben" des Topos in Apg 2, 44 und 4, 32, in Fornberg, T \& Hellholm, D (eds), Texts and Contexts: Biblical texts in their textual and situational contexts. 689-711. Oslo: Scandinavian University Press.

Theissen, G 2002. Die politische Dimension des Wirkes Jesu, in Stegemann, W, Theissen, G \& Malina, B J (Hrsg), Jesus im neuen Kontexten, 112-122. Stuttgart: Kohlhammer.

Tidball, D 1983. An introduction to the sociology of the New Testament. Exeter: Paternoster.

Troeltsch, E [1911] [1931] 1950. The social teaching of the Christian churches. 2 Volumes, tr by O Wyon. London: George Allen \& Unwin/New York: Harper \& Brothers. (Halley Stewart Publications 1.)

Turner, J H [1982] 1991. The structure of sociological theory. Belmont: Wadsworth.

Van Aarde, A G 1993. Aspekte van die sosiale stratifikasie van die ontwikkelde agragriese samelewing in die eerste-eeuse Palestina. HTS 49, 515-545.

Van Aarde, A G 1994a. A silver coin in the mouth of a fish (Mt 17:24-27): A miracle of nature, ecology, economy and the politics of holiness, in Van Aarde, A G, God-with-us: The dominant perspective in Matthew's story and other essays, 204-228. Pretoria: Gutenberg. (HTS Suppl 5.)

Van Aarde, A G 1994b. Kultuurhistoriese agtergrond van die Nuwe Testament: Die eerste-eeuse Mediterreense sosiale konteks. Pretoria: Kital. 
Van Aarde, A G 1994c. Kultuurimperialisme as 'n hermeneutiese dilemma: Eerstewêreldse en Derde-wêreldse perskpektiewe op Jesus as die Seun van God. HTS 50(1\&2), 354-367.

Van Aarde, A G 1994d. The epistemic status of the New Testament and the emancipatory living of the historical Jesus in engaged hermeneutics. Neotestamentica 28(2), 575-596.

Van Aarde, A G 1996. Armoedekultuur: Die leefwêreld van die Nuwe Testament en die situasie in Suid-Afrika vandag. HTS 52(4), 947-964.

Van Aarde, A G 2000. Understanding Jesus' healings. Scriptura 18, 1-19.

Van Aarde, A G 2001a. Fatherless in Galilee: Jesus child of God. Harrisburg, PA: Trinity Press International.

Van Aarde, A G 2001b. Millennialisme, eskatologie en apokaliptiek. HTS 57(3\&4), $1158-1178$.

Van Aarde, A G 2002. Methods and models in the quest for the historical Jesus: Historical criticism and/or social scientific criticism? HTS 58(2), 419-439.

Van Aarde, A G 2005a. Ebionite tendencies in the Jesus tradition: The Infancy Gospel of Thomas interpreted from the perspective of ethnic identity. Neotestamentica 40(2) 353-382. (Paper presented at the Social Scientific Criticism section of the Society of Biblical Literature Meeting at Philadelphia, GA, 19-22 November 2005.)

Van Eck, E [1994] 1995. Galilee ad Jerusalem in Mark's story of Jesus: A narratological and social scientific reading. Pretoria: Promedia. (HTS Supplementum 7.) [A reworked version of DD Dissertation, University of Pretoria, 1994.]

Van Staden, P \& Van Aarde, A G 1991. Social description or social-scientific interpretation? A survey of modern scholarship. HTS 47, 55-87.

Von Dobschütz, E 1904. Christian life in the primitive church, tr by $\mathrm{G}$ Bremmer and ed by W D Morrison. London: Willimas and Norgate.

Von Harnack, A [1902] 1908. The mission and expansion of Christianity. 2 Volumes. London: Williams \& Norgate.

Vorster, W S 1988. Toward a post-critical paradigm: Progress in New Testament scholarship?, in Mouton, J, Van Aarde, A G, Vorster, W S (eds), Paradigms and progress in theology, 31-48. Pretoria: Human Research Council.

Vledder, E-J [1994] 1997. Conflict in the miracle stories: A socio-exegetical study of Matthew 8 and 9. Sheffield: Sheffield Academic Press. (JSNS Series 152.) [A reworked version of DD Dissertation, University of Pretoria, 1991.]

Vledder, E-J \& Van Aarde, A G 1994. The social stratification of the Matthean community. Neotestamentica 28(2), 511-522.

Vledder, E-J \& Van Aarde, A G 1995. The social location of the Matthean community. HTS 51(2), 388-408.

Waetjen, H C 1989. A reordering of power: A socio-political reading of Mark's gospel. Minneapolis, MN: Fortress.

White, L M 1991. Crisis management and boundary maintenance: The social location of the Matthean community, in Balch, D L (ed), Social history of the Matthean community. 211-247. Minneapolis, MN: Fortress.

Wilson, B R 1870. Religious sects: A sociological study. London: Weidenfeld \& Nicholson. (World University Library.) 
Wilson, B 1973. Magic and millenium: A sociological study of religious movements among tribal and third world peoples. London: Heinemann.

Wilson, R R 1984. Sociological approaches to the Old Testament. Phildelphia, PA: Fortress.

Zimmermann, H [1967] 1974. Neutestamentliche Methodenlehre: Darstellung der historisch-kritischen Methode. 4. Auflage. Stuttgart: Verlag Katholisches Bibelwerk.

Zuckermann, P 2003. Invitation to the sociology of religion. New York: Routledge. 